\title{
UNDERSTANDING THE LEVELS OF SATISFACTION AMONG UNIVERSITY STUDENTS ABOUT THE USE OF ICTS
}

\author{
Ali Abbas \\ Department of Sociology, Quaid-i-Azam University, Islamabad \\ Email: Ali463852@gmail.com \\ Sana Mehmood \\ Visiting Lecturer, Department of Sociology \& Anthropology, \\ Karakoram International University, Gilgit \\ Email:sanaraja310@gmail.com \\ Saadia \\ Gender and Learning Specialist, \\ Planning and Development Department \\ Khyber Pakhtunkhwa, Peshawar \\ Email: saadiakn07@gmail.com
}

\begin{abstract}
The aim of this study was to understand the satisfaction levels of undergraduate students of Quaid-i-Azam University (QAU), Islamabad about the usage of Information and Communication Technologies (ICTs) for their academic purposes. The quantitative research approach was applied to collect data through a survey method from two hundred (200) sampled respondents from three faculties of QAU i.e., social science, natural science, and biological sciences. The convenient sampling technique was used for the selection of the respondents. A well-structured questionnaire was used for the survey purpose. Some of the questionnaires were self-administered while the rest were distributed among the respondents and collected later. The data were analyzed in Statistical Package for Social Science (SPSS) and both descriptive and inferential statistics were applied. The findings of the study showed that undergraduate students at $Q A U$ were using the internet, having sufficient knowledge of ICTs, and were using these ICTs for educational purposes, such as research work, class assignments, and communication with teachers. The Confidence Interval was [95\% and MoR was 0.05). All the figures had less than 0.05 values which means the variables are correlating to each other. Some of the respondents stated that there is a lack of ICTs well-trained staff and limited space in the computer laboratories at the campus. The university administration should pay special attention to the provision of ICTs to the student so that they could get maximum benefits out of it. Moreover, the respondent's knowledge about the usage of ICTs has a strong relationship with the students' attitude towards the ICTs use. The respondent's level of knowledge about the ICTs has a less likely effect on the major constraint in using ICTs.
\end{abstract}

Keywords: Information and Communication Technologies, Quaid-i-Azam University, Cognitive Flexibility, Academic Activities, Internet, Pakistan.

\section{INTRODUCTION}

The Information and Communication Technologies (ICTs) is a broader term used for Information Technology (IT), which refers to all communication technologies, including the internet, wireless networks, cell phones, computers, software, middleware, videoconferencing, social networking, and other media applications and services enabling users to access, retrieve, store, transmit, and manipulate information in a digital form (AIMS, 2020). It is now getting more importance in the higher education system and daily life's activities. The ICTs in the mode of education that use the information and communications technology to support, enhance, and optimize the delivery of information (Linways, 2017).

The use of ICTs has made it much easier for the students to learn swiftly and are used across the world for better understanding. The internet is used by the faculty members, teachers, students, and administrative staff as a source of information, such as, in research, report writing, assignment writing, 
online presentations, and transferring different files and documents from one place to another place. The internet revolution has narrowed down the information gap. The electronic way of study and knowledge is easier for students, teachers, and other staff. ICTs make life easy, such as the traditional libraries are converted into digital forms, where one can find a bunch of knowledge and books with only one click. Both the graduate and undergraduate students are now experiencing a shift from the traditional to the modern level and technology-based information system. The traditional classrooms are transformed into modern electronic classrooms through which the delivery of electronic content has made very easy (Oliver, 2002). The present pandemic situation has strengthened the more reliance of education on the use of digital platforms for the transfer of knowledge. The teachers are now using online platforms for daily classes since educational institutions are being shut down due to the reasons that the Coronavirus (COVID-19) spread is inevitable (König, Jäger-Biela \& Glutsch, 2020).

The ICTs are now generally accepted and recognized as modern instruments, tools, and techniques, which enables the teacher's and students' interests through modification of the knowledge that enhances the students' academic skills. The extension of the usages of the ICTs at the university level droves the traditional learning environment into the modern way of knowledge. The use of information technology plays an important role for educational institutions and students to enlarge their academic engagements and it also improves the student's satisfaction levels (Saupe, Smith \& Xin, 1999). The successful implementation of ICTs based education requires to update knowledge and techniques. Similarly, Hoffman (2001) stated that the successful implementations of the ICTs need to address the important five interlock framework for change in the education system.

The ICTs implementation has different techniques in education and in the learning process at the university level among the students. These techniques are included video calling, telephonic conversation, video conferencing, and other e-learning techniques. These tools and techniques are used in education for different purposes, such as, to improve the students learning skills, enhanced the communication skills of students, enhanced the student's confidence, and make the instruction more meaningful (Valasidou et al., 2005). These tools and techniques improve the student's satisfaction level in their studies and build their confidence level. On the other hand, the usages of these modern technologies have different aspects like positive and negative both. The positive uses of information technologies improve the students' knowledge and enhance their educational background. Moreover, the negative uses of information technologies are a waste of the time of students, especially, undergraduate university students, who are not reached at the ages of maturity. These students waste their time on social media and are involved in unwanted chatting and conversation with each other, which wastes their time and divert their attentions from studies to entertainment related activities.

The use of ICTs is often considered as the catalyst of the social, political, economic change in society. These changes have imperative impacts on the educational institutions, where the methods of teaching style, learning approaches, access to the information, and presenting the knowledge in a concise manner (Watson, 2005). These information technologies provide vibrant accessibility to modern information technologies and communication systems (White, 2010). The ICT's capacities are fundamentals to the participation and engagements in the modern educational society. Through, the use of these ICTs solutions for existing problems is sought in a better manner. The ICTs allow people globally to interact with each other and share their views and ideas and seek feedbacks from their inter-conversations. The prime purpose of the current study was to understand the prevalence of use of ICTs and the level of satisfaction among the undergraduate students at Quaid-i-Azam University, Islamabad.

\section{REVIEW OF LITERATURE}

Education is an important and key area where the ICTs are applied to a significant level. It can provide the best alternative solutions for any academic problem in the educational system (Casal, 2007:05). The important and vibrant purpose of the usage of the ICTs is in an educational domain where familiarity with the use of modern technology is obtained for study and learning processes. The information technology consisted of computers, the internet, and other social media means. The ICTs provide the learning process through even online games and sports which help students to develop their educational skills (Gateway, 
2010). By using this modern information and technologies, where students can reach with information within a second. Students and teachers can have access to online e-books, research journals, and other related study websites. These means and methods can improve the students learning process. The modern technologies included wireless networks, the internet, different search engines, database websites, websites, and many other web-related technologies.

Moreover, Maharana, Biswal \& Sahu (2009:12) examined that the usage of the technology and new means of communications by the medical students and found them very satisfied. According to the findings of the study, approximately $77 \%$ of the respondents have stated that the ICTs must be made part of their syllabus. Similarly, $98 \%$ of the respondents have also desired to have access to the digital computer system and modern digital laboratories in their academic institutions. Almost one hundred students out of one hundred and twenty-eight in total were strongly agreeing that medical education is not effective and reached a higher level of understanding without the ICTs based resources and services. Students in such colleges, where the modern digital computer laboratories were available, got higher marks in examinations. So, there is a positive relationship between the use of modern technology and the level of marks gained in the examination. the student's satisfaction is depending on the means and methods of teaching, learning, and acquiring knowledge in the academic institutions. The more experts in the usage of modern technology, the higher the chances of maximized marks in any examination.

The Information Communication Technologies (ICTs) are referred to the convergence of media technology such as audio-visual and telephone networks with computer networks, by means of a unified system of cabling (including signal distribution and management) or link system. However, there is no universally accepted definition of ICTs considering that the concepts, methods, and tools involved in ICTs are steadily evolving on an almost daily basis (AIMS, 2020). ICTs are one of the important mottos of the modern world to provide better educational facilities for the institutions in the world (Latchem, 2017).

The ICTs have transformed the traditional society into an information society and changed the lives of people including students. The ICTs have integrated the diverse knowledge into a single platform. The ICTs have played a vigorous role in knowledge production and dissemination to the advanced educational society. Nowadays, libraries are digitalized and equipped with modern communication systems. All information is available with one click. Many libraries have made their ICTs applications user-friendly (Youssef \& Dahmani, 2008). Many students and teachers get online books from different digital libraries through the internet. Information and communication technology are the fusion of computers and telecommunications. It also describes the existing and innovative ways to provide lifelong learners, i.e., students with easy access to the information. Modern technology, particularly computers make people's life very easy. Through the usage of modern technologies students and teachers work on research, get access to online books and materials (Master \& Arul Sekar, 2016).

Thanuskordi and Subramaniyan (2013) found that India has improved their performance in the $21^{\text {st }}$ century in the usage of information and communication technologies at every walk of life. ICTs are largely used in their academics as well as in the development sectors. The students of India have online studies accounts in huge numbers after America and China. In India, the majority of the libraries in the universities are equipped with modern technologies and updated ICTs tools and techniques. Digital libraries play a vital role in enhancing the intellectual development of students. Formal education can be conducted effectively and very efficiently only through the provision of well-equipped libraries. Today's digital libraries relate to other libraries around the world. The higher transformation of knowledge is only possible through the proper utilization of ICTs at educational institutions (Almarabeh et al., 2014).

The usages of the ICTs are now getting an important role and are need of the time in higher education in Pakistan. Today's majority of academic activities are done by using technologies. The computer is the main component of this era. The students and teachers use ICTs for research, presentation, online lectures, making assignments, etc. Similarly, undergraduate students are also using modern information communication technologies in their studies for (a) making presentations and assignments, (b) for thesis preparations, and (c) for daily classes especially during the Coronavirus spread. The proper use of ICTs helps them to accomplish their academic goals well in time with utmost accuracy (Makura, 2014). 
Moreover, Oliver (2002), found that the role of ICTs in the higher education system or the levels in the present $21^{\text {st }}$ century has played an important role. The ICTs have offered students a centered learning process, constructive knowledge, provide distance learning at any time and from any place. The ICTs have improved many dimensions of education and developed the educational domain on scientific grounds. The learning should be more students and teachers oriented and contents shall be relevant to the needs of the students. The undergraduate students have also improved their studies through the ICTs, which combine knowledge and provide it at a single platform (Slechtova, 2015).

On the other hand, ICTs has also negative impacts on the students' academic activities like wasting their time on social media accounts, hacking personal information, harassing people, unwanted sharing of unethical content. These activities show that ICTs have also non-academic uses. A study conducted by Luambano and Nawe (2004:08) stated that the usages of the internet by the students of the university of Dare-es-Salaam in Tanzania, where the results showed that most of the students were not well aware of the using the techniques of internet and the ICTs for academic purposes. The second reason was the students were not properly using the internet for academic purposes, because of the inadequate computer knowledge, lack of facilities, lack of internet-related skills, and the slow speed of the internet. The findings also stated that students who use the internet are less useful for academic purposes. The recommendations of that study were found that more computers should be connected to the internet connection, students should provide the ICTs training, upgraded internet speed shall be provided in the educational institutions (Marcino, 2018).

A study conducted by Nisar, Munir, and Shad (2011) in Pakistan found that the respondents were agreeing that usage of ICT brings a positive impact on the education sector of Pakistan. They are agreeing that the usage of ICT improves their knowledge skills and helps to deliver better results (Basri, Alandejani \& Almadani, 2018). They are also agreeing that ICT is efficiently used in the education sector of Pakistan and enhanced their planning regarding education. Another study in the case of Pakistan concluded that Pakistan is far behind in the integration process and a poor ICTs- related development is observed. There are numerous hurdles in the effective integration of ICTs into education, especially the school level education (Taimur-ul-Hassan \& Sajid, 2013).

\section{METHODOLOGY}

The quantitative research strategy was used to conduct this research study at QAU, Islamabad, Pakistan. The universe of this study was the faculty of social sciences, natural sciences, and biological sciences. The students, both male and female, who were doing their undergraduate studies from (social science, natural science, and biological sciences) were taken as the unit of data collection. Due to the diversification in the population, the researchers have only focused on the undergraduate or (BS Hons) students, because they were more involved in the use of ICT tools and techniques. The convenient sampling technique was adopted to collect the data because it was one of the easiest to access the respondents through this technique. For this research study data were collected preferred of two hundred (200) respondents. Statistical Package for Social Sciences (SPSS) was used for descriptive and inferential analyses.

\section{MAJOR FINDINGS}

This section presents the major quantitative findings of the study while in the first section information about the basic demographic profile of the respondents and the use of ICTs is given to get a basic understanding.

Table 1. Demographic Profile

\begin{tabular}{|l|c|l|c|}
\hline Categories & \% & \multicolumn{1}{c|}{ Categories } & \% \\
\hline Gender & 80.0 & Faculty & 44.5 \\
\hline Male & 40.0 & Nocial Science & 33.0 \\
\hline Female & & Biological Sciences & 22.5 \\
\hline Age & 41.0 & Residential Status & \\
\hline $16-20$ & 54.5 & Day Scholar & 50.5 \\
\hline $21-25$ & 4.5 & University's Hostel & 40.0 \\
\cline { 3 - 4 } $25>$ & & Any Other & 9.5 \\
\hline
\end{tabular}


The table 1 showed the gender of respondents, whereas $80 \%$ Male and $40 \%$ were Female. The conclusion of the table stated that male was more than female. The table showed the age of respondents, where $41.0 \%$ were between $16-20,54.5 \%$ were between $21-25,4.5 \%$ were more than 25 years old. The table showed the department, $44.5 \%$ were belonged to social science, $33.0 \%$ were belonged to natural science and rest of $22.5 \%$ were belong to the biological sciences. The table showed the residential status of respondents, where $50.5 \%$ were day scholar, $40.0 \%$ were living in university's hostel and $9.5 \%$ were responded any other.

Table 2. The Use of ICTs

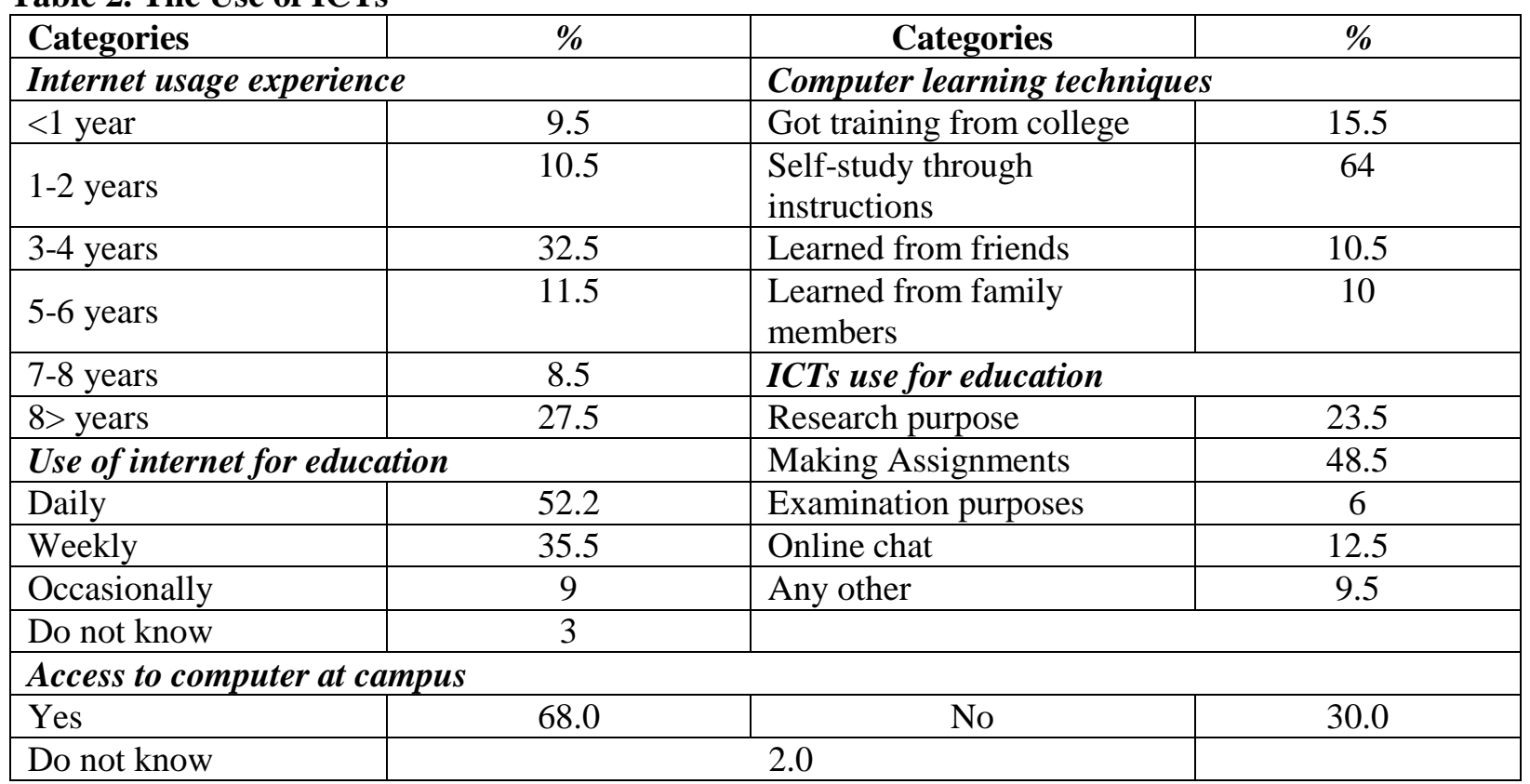

The table 2 showed the experiences of the internet usage, where $9.5 \%$ have less than 1 year, $10.5 \%$ have 1-2 years, $32.2 \%$ have 3-4 years, $11.5 \%$ were $5-6$ years, $8.5 \%$ were $7-8$ years, and $27.5 \%$ were more than 8 years. The table showed the using internet for educational purpose, whereas $52.2 \%$ were using daily, $35.5 \%$ were using weekly, $9 \%$ were occasionally and $3 \%$ were do not know. The table showed the utilization of ICTs for the activities, whereas $23.5 \%$ were using for the research purpose, $48.5 \%$ were using for making their assignments, $6 \%$ for examination purposes, $12.5 \%$ for online chatting and $9.5 \%$ were using for some other purposes. The table showed the computer skills learning methods, whereas $15.5 \%$ got training from college, $64 \%$ through self-study instruction, $10.5 \%$ learnt from friends and $10 \%$ from their family members.

Table 3. Percentage Distribution of Variables (Items)

\begin{tabular}{|l|l|l|}
\hline \multicolumn{2}{|l|}{ Respondents Knowledge about the ICTs } \\
\hline Yes (\% in Weight) & No (\% in Weight) & Don't Know (\% in Weight) \\
\hline 74.85 & 19.8 & 5.35 \\
\hline \multicolumn{1}{|l|}{ The Overall Attitude of Students about The Usage of ICTs and Satisfaction Levels } \\
\hline Yes (\% in Weight) & No (\% in Weight) & Don't Know (\% in Weight) \\
\hline 66.86 & 28.4 & 4.6 \\
\hline Major Constrain in the Use of ICTs & No (\% in Weight) & Don't Know (\% in Weight) \\
\hline Yes (\% in Weight) & 52.7 & 10.8 \\
\hline 47.5 & \multicolumn{2}{|l|}{} \\
\hline
\end{tabular}


Table 3 showed the average percentage (weight) of the variables. The items at every section have sum their responses and divided with the number of cases. Furthermore, $74.85 \%$ respondents have updated knowledge about the usage of ICTs. Whereas $66.86 \%$ of respondents were satisfy of the usage of ICTs and finally, $47.5 \%$ of respondents have faced constraints while using the ICTs.

Table 4. Reliability Statistics

\begin{tabular}{|c|c|c|}
\hline Cronbach's Alpha & $\begin{array}{c}\text { Cronbach's Alpha Based on } \\
\text { Standardized Items }\end{array}$ & $\mathrm{N}$ of Items \\
\hline .805 & .789 & 33 \\
\hline
\end{tabular}

In order for the global scale to have good reliability, the Cronbach's alpha should be fairly high (a commonly used threshold is 0.7 ). The closer Cronbach's alpha is to 1, the more likely is that the items in the scale measure the same underlying concept. In order to measure the reliability three sections have been taken: (1) Respondents Knowledge about the ICTs where 10 measurable items were included, (2) The Attitude of Students about The Usage of ICTs and Satisfaction Levels which included 11 items and finally (3) The Major Constrain in the Use of ICTs which included total 9 items. The validity of subscale, consisting of thirty-three (30) items, was found to be highly reliable where the $(a=.805)$. Hence the value is more closed to 1 , which means the data is highly reliable.

Hypothesis-1: The respondent's knowledge about the usage of ICTs have a positive relationship with the students' attitude towards the ICTs use.

Table 5. Descriptive Statistics

\begin{tabular}{|c|c|c|c|}
\hline & Mean & Std. Deviation & $\mathrm{N}$ \\
\hline RKICT & 1.3050 & .27904 & 200 \\
\hline RAICT & 1.3777 & .24114 & 200 \\
\hline
\end{tabular}

The table 5 showed the descriptive analysis of the selected items: RKICT: Means Respondents Knowledge about the usage of ICTs, where total 10 items were selected and RAICT: Means the overall attitude of students about the usage of ICTs and their satisfaction levels towards ICTs, where total 11 items were included. Three scales were developed; Yes, No and Don't Know. The mean score showed that students have knowledge about the usage of ICTs and their attitude was positive and they were satisfied towards the ICTs utilization.

Table 6. Correlations

\begin{tabular}{|l|l|r|r|}
\hline \multicolumn{2}{|c|}{ RKICT } & RKICT & RAICT \\
\cline { 2 - 4 } & Pearson Correlation & 1 & $.303^{* *}$ \\
\cline { 2 - 4 } & Sig. (2-tailed) & & .000 \\
\hline \multirow{2}{*}{ RAICT } & Pearson Correlation & $.303^{* *}$ & 1 \\
\cline { 2 - 4 } & Sig. (2-tailed) & .000 & \\
\hline \multirow{2}{*}{$* *$. Correlation is significant at the 0.01 level (2-tailed). }
\end{tabular}

Pearson Correlation Test was applied to know about the relationship/association between the respondent's knowledge about the usage of ICTs have a relationship with the students' attitude towards the ICTs use. There was a positive correlation between the knowledge of ICTs and usage/satisfaction level, $\mathrm{r}=$ $.303, \mathrm{n}=200, \mathrm{p}=.000$, which is less than alpha value 0.05 . Hence, there is a strong, positive correlation 
between the respondent's knowledge about the usage of ICTs, have a relationship with the students' attitude towards the ICTs use.

Hypothesis-2: The respondents level of knowledge about the ICTs has effects with the major constraint in using ICTs.

Table 7. Descriptive Statistics

\begin{tabular}{|c|c|c|c|}
\hline & Mean & Std. Deviation & $\mathrm{N}$ \\
\hline MCICT & 1.6328 & .39793 & 200 \\
\hline RKICT & 1.3050 & .27904 & 200 \\
\hline
\end{tabular}

MCICT: Major Constrain in the Use of ICTs.

RKICT: Respondents Knowledge about the ICTs

The descriptive statistics showed that the mean score of majors constrain faced by students about the usage of ICTs is 1.63 with the standard deviation of .397 which is quite less. Similarly, the mean hours of knowledge about the usages of ICTs were 1.305 with the standard deviation of .2790 . The conclusion of the table showed that knowledge about the usage of ICTs have less effects the constrain, which is around $39 \%$.

Table 7. Correlations

\begin{tabular}{|l|l|r|r|}
\hline \multicolumn{2}{|c|}{} & MCICT & \multicolumn{2}{c|}{ RKICT } \\
\hline \multirow{2}{*}{ Pearson Correlation } & MCICT & 1.000 & .314 \\
\cline { 2 - 4 } & RKICT & .314 & 1.000 \\
\hline \multirow{2}{*}{ Sig. (1-tailed) } & MCICT &. & .000 \\
\cline { 2 - 4 } & RKICT & .000 &. \\
\hline
\end{tabular}

The correlation matric stated that, there is a positive correlation that the respondents level knowledge about the ICTs have effects with the major constraint in using ICTs, but there is less correlation, which is weak. The value $\mathrm{r}=.314$ which is less tended towards 1 , which stated that, it little/less correlation, and the $\mathrm{p}=$ .000 which is less than alpha value 0.05 . The correlation matric is statistically significance, and the chances of correlation is approximately $31 \%$.

Table 8. Model Summary ${ }^{\mathrm{b}}$

\begin{tabular}{|c|c|c|c|c|c|c|c|c|c|}
\hline \multirow{2}{*}{$\begin{array}{l}\text { Mod } \\
\text { el }\end{array}$} & \multirow[t]{2}{*}{$\mathrm{R}$} & \multirow{2}{*}{$\begin{array}{l}\mathrm{R} \\
\text { Square }\end{array}$} & \multirow{2}{*}{$\begin{array}{l}\text { Adjusted } \\
\text { R Square }\end{array}$} & \multirow{2}{*}{$\begin{array}{l}\text { Std. } \\
\text { Error of } \\
\text { the } \\
\text { Estimate }\end{array}$} & \multicolumn{5}{|c|}{ Change Statistics } \\
\hline & & & & & $\begin{array}{l}\mathrm{R} \\
\text { Square } \\
\text { Change }\end{array}$ & $\begin{array}{l}\mathrm{F} \\
\text { Change }\end{array}$ & df1 & df2 & $\begin{array}{l}\text { Sig. } \\
\text { F } \\
\text { Chan } \\
\text { ge }\end{array}$ \\
\hline 1 & $.314^{\mathrm{a}}$ & .099 & .094 & .37872 & .099 & 21.703 & 1 & 198 & .000 \\
\hline
\end{tabular}

This table provides the $\mathrm{R}$ and $\mathrm{R}^{2}$ values. The $\mathrm{R}$ value represents the simple correlation and it is .314 (the "R" Column), which indicates a less degree of correlation, similarly, value represent the relationship where it is strong when it near to 1 (Simple Correlation), correlation coefficient between two variables. The $\mathrm{R}^{2}$ value (the "R Square" column) indicates how much of the total variation in the dependent variable, major 
constrain in usage of ICTs, can be explained by the independent variable, knowledge about the usage of ICTs. In this case, $.099 \%$ can be explained, which is very small effects.

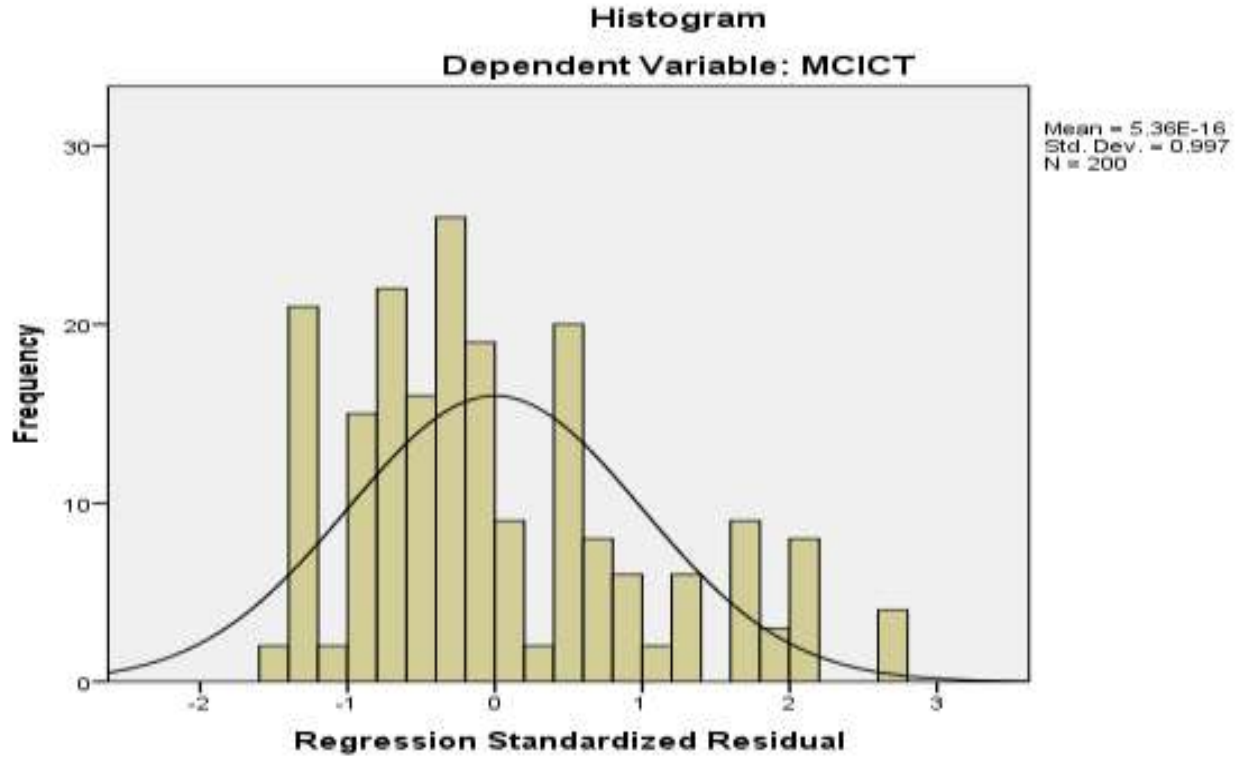

Normal P.P Plot of Regression Standardized Residual

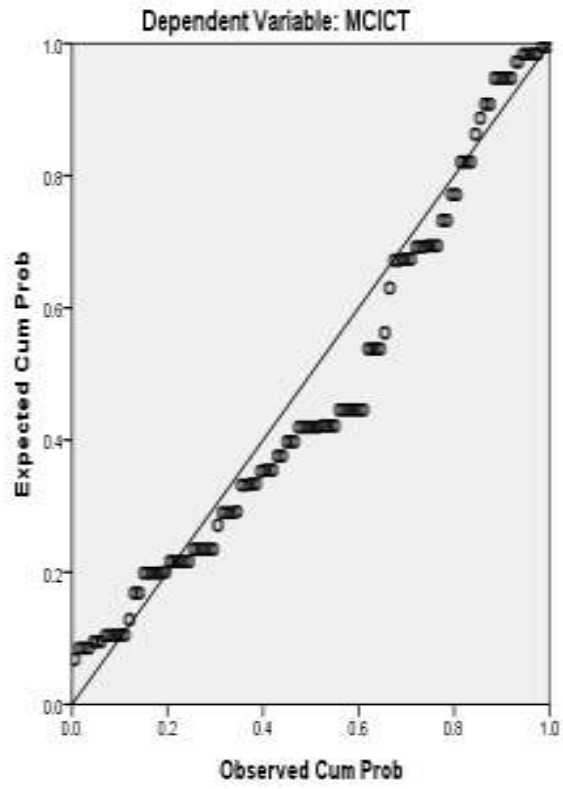

Scatterplot

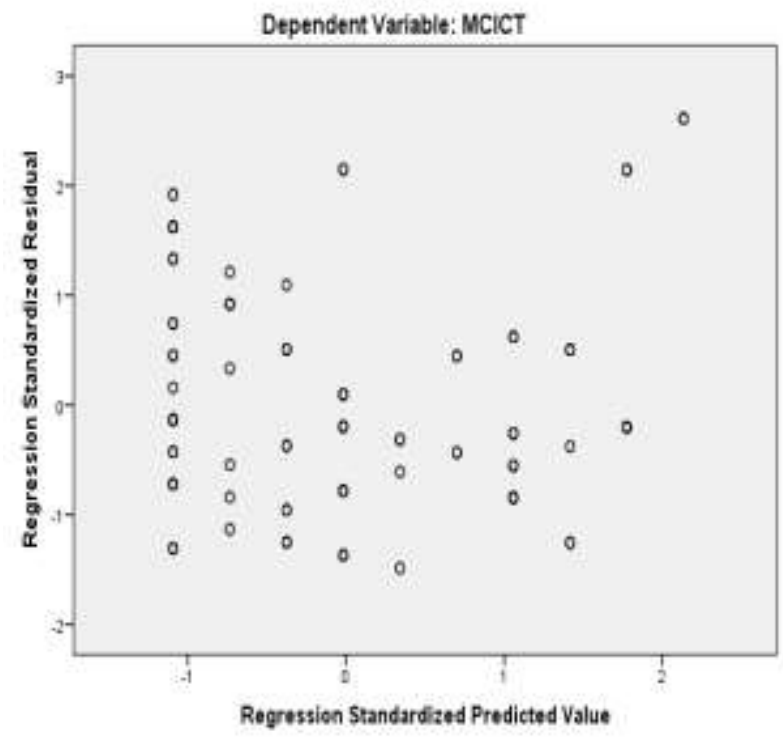

\section{DISCUSSION}

The research examines the level of satisfaction among the undergraduate students of QAU, Islamabad, regarding the usages of Information and Communication Technologies. The quantitative research approach was used, and data were collected from the undergraduate students of QAU, through the closed-ended structured questionnaires. The SPSS was the tool that analyzed the collected data in table forms. Both the 
inferential and descriptive statistics were applied to present the data, the findings of the research showed that majority of $80 \%$ of respondents were male, whereas there were $40 \%$ of the respondents who had experience of internet usages between 3-5 years and $46 \%$ of the respondents had more than eight-year of internet using experiences in total. The use of ICTs has been getting more attention in higher education. The internet is used by the faculty, supporting staff, students, and admin staff as the source of information, such as for research, report writing, assignment writing, online presentations, and transferring different files and documents from one place to another place. Similarly, the above results of the current research also showed that majority of 53\% of respondents were using the computer and the other ICTs tools for educational purposes and most of them $48.5 \%$ of the respondents were using the computer for making class assignments and the rest of $23.5 \%$ of respondents were using the ICTs for research purpose at the university.

Furthermore, the internet revolution has narrowed down the information gap. The electronic way of study and knowledge is easier for students, teachers, and other supporting staff. The ICTs make life easier as compared to the traditional means and methods, which changed the traditional libraries into the electronic way, where one can find a bunch of knowledge and book with one click (Valasidou \& Bpusiou, 2005). Both the graduate and undergraduate students are experiencing to drift from the traditional to the modern level. The traditional classrooms are transformed into the modern electronic-based classroom and the delivery of electronic content from even other countries through the field experts. Similarly, the present research stated that $68.5 \%$ of respondents saved their study time and $85 \%$ found the ICTs helpful for selfstudy. Moreover, $85 \%$ of respondents stated that usage of ICTs is helpful for future jobs. Furthermore, $86 \%$ of respondents have said that they have enhanced their overall academic performance.

The use of information and communication technologies is nowadays needed in higher education in Pakistan. Today's most academic activities have been done by using technologies and the internet. The computer is the main component of this era and it is playing its major role in the development of academics. The students and teachers use ICTs for research, presentation, online lectures, making assignments, etc. Similarly, the undergraduate students were also using modern information communication technologies in their studies, making presentations and assignments, and making a thesis, etc. The ICTs have helped them out to work on time with accuracy. Students and teachers at QAU, Islamabad were also using information communication technologies in their studies. At Quaid-i-Azam University, all the departments have started undergraduate programs (BS Programs) due to the new policy of Higher Education Communication (HEC). The undergraduate students are provided with facilities of modern ICTs and students are now availing these technologies which have enhance their academic activities.

In line with the current study's findings, Oliver (2002:05) stated that the role of the ICTs in the higher educational level in the era of the $21^{\text {st }}$ century has played an important role in academic development and research. The ICTs have offered students centered learning process, constructive knowledge, provide the distance learning process at any time and from any place at a cheaper cost. The ICTs have improved many dimensions of education and developed the educational domains. The undergraduate students have also improved their studies through the ICTs, which combine knowledge and provide it at a single platform. However, the usage of ICTs is depending on the level of knowledge. The present study presents that $74.85 \%$ of respondents were having the perfect level of knowledge about the usage of ICTs at QAU, 19.8\% had no knowledge and finally $5.35 \%$ were not sure whether they had the perfect level of knowledge or not. Moreover, the level of knowledge had a positive impact on the satisfaction levels of respondents. At QAU the knowledge is correlated with the satisfaction levels. The results showed that $66.86 \%$ of respondents were satisfied, $28.4 \%$ of respondents were not and $4.6 \%$ of respondents were not yet decided. Finally, $47.5 \%$ of respondents were finding constraints in utilizing the ICTs and $52.7 \%$ did not find any type of difficulty.

On the other hand, the uses of ICTs have also negative impacts on the students' academic activities and performance, such as the wastage of time on social media accounts, hacking personal information, harassing people. These activities show that the ICTs have also non-academic usage for some of the students. The findings of the research showed that the majority of the students were not using the internet or ICTs for academic purposes. However, the inferential results also stated that the usage of ICTs have more likely positive impacts on the academic performance among the students. 


\section{CONCLUSION}

The research examines the satisfaction level among the undergraduate students' regarding the usages of the ICTs at QAU, Islamabad. The ICTs become an important and vital part of the student's life, where all the academics discussions are being done through the ICTs tools and techniques. Nowadays even students do not think to study without the internet and ICTs. The usages of the ICTs save study time and makes life easy. In this modern era teachers normally teach through the ICTs and students also have access to online lectures from experts across the world. The use of the ICTs tools and techniques were ranged from making assignments to research work and other classroom activities. The ICTs facilitate the students learning skills and teachers' teaching process. At QAU where the majority of students were using the ICTs and other related tools and techniques and also having a piece of complete knowledge and skills to use the ICTs in a better way. They know the importance of ICTs for their studies, and entertainment. Most of the respondents have stated that they have internet access at the campus and off the campus as well. Moreover, the majority of students were using the internet for educational purposes. On the other hand, some of the respondents have also stated that there is a miss management in the digital lab where the ICTs staff are inadequate in numbers and do not having the sufficient knowledge. There is a digital lab on campus, but the space is limited so this is why many students face difficulties to access to the digital library. The management needs to address the student's concerns and make the arrangement of ICTs in the lab so that students can get the maximum benefits out of it.

\section{REFERENCES}

AIMS. (2020). Information and communication technologies (ICT). Retrieved from http://aims.fao.org/information-and-communication-technologies-ict

Almarabeh, T., Mohammad, H., Yousef, R., \& Majdalawi, Y. K. (2014). The University of Jordan elearning platform: State, students' acceptance and challenges. Journal of Software Engineering and Applications, 7(12), 999.

Basri, W. S., Alandejani, J. A., \& Almadani, F. M. (2018). ICT adoption impact on students' academic performance: Evidence from Saudi universities. Education Research International, 2018.

Casal, R. C. (2007). ICT for education and development. Info. 9(4), 3-9.

Gateway, D. R. (2010). Defining ICT in education. Retrieved from: http://www.rwandagateway.org/ICT4E/spip.php?rubrique6

Hoffman, A. J. (2001). Linking organizational and field-level analyses: The diffusion of corporate environmental practice. Organization \& Environment, 14(2), 133-156.

König, J., Jäger-Biela, D. J., \& Glutsch, N. (2020). Adapting to online teaching during COVID-19 school closure: teacher education and teacher competence effects among early career teachers in Germany. European Journal of Teacher Education, 43(4), 608-622.

Latchem, C. (2017). Using ICTs and blended learning in transforming technical and vocational education and training. UNESCO Publishing.

Linways. (2017). ICT enabled education: The alchemy of mixing technology and education. Retrieved from https://stories.linways.in/ict-enabled-education-d190bcc91bf0

Luambano, I., \& Nawe, J. (2004). Internet use by students of the University of Dare-es-Salaam. Library Hi Tech News, 21(5), 13-17.

Maharana, B., Biswal, S., \& Sahu, N. K. (2009). Use of information and communication technology by medical students: A survey of VSS Medical College, Burla, India. Library Philosophy and Practice (e-journal), 281. https://digitalcommons.unl.edu/libphilprac/281

Makura, A. H. (2014). Students' perceptions of the use of ICT in a higher education teaching and learning context: The case of a South African University. Mediterranean Journal of Social Sciences, 5(11), 43-47.

Marcino, P. (2018). Impact of information and communication technology on academic achievement for exceptional student education inclusion students. $\mathrm{PhD}$ Dissertation. Walden University. https://scholarworks.waldenu.edu/dissertations/4801 
Master, J., \& Arul Sekar, J. M. (2016). Awareness of B.Ed. students towards information and communication technology (ICT). In E. Ramganesh, Dr. I. Muthuchamy, Dr. S. Senthilnathan, Dr. S. Amutha, and Dr. S. Alfred Cecil Raj (eds.), Higher education in knowledge age: Technopedagogical perspectives and innovations Edition (pp. 1-7). Department of Educational Technology, Bharathidasan University, Tiruchirappalli and St. Joseph's College, Tiruchirappalli.

Nisar, M. W., Munir, E. U., \& Shad, S. A. (2011). Usage and impact of ICT in education sector: A study of Pakistan. Australian Journal of Basic and Applied Sciences, 5(12), 578-583.

Oliver, R. (2002). The role of ICT in higher education for the 21st century: ICT as a change agent for education. International Journal of 3600 Management Review, 7, 17-20. Available: http://elrond.scam.ecu.edu.au/oliver/2002/he21.pdf

Saupe, J. L., Smith, T. Y., \& Xin, W. (1999). Institutional and Student Characteristics in Student Success: First-Term GPA, One-Year Retention and Six-Year Graduation. Paper presented at the annual meeting for the Association for Institutional Research, Seattle, WA.

Slechtova, P. (2015). Attitudes of undergraduate students to the use of ICT in education. Procedia-Social and Behavioral Sciences, 171, 1128-1134.

Taimur-ul-Hassan, \& Sajid, A. R. (2013). ICTs in Learning in Pakistan. Journal of Research and Reflections in Education, 7(1), 52-64.

Thanuskodi, S., \& Subramaniyan, S. (2013). Awareness and use of e-resources among library and information science distance learners at Alagappa University: A study. In A. Sigal (Ed.), Advancing Library Education: Technological Innovation and Instructional Design (pp. 264-272). Information Science Reference.

Valasidou, A., Sidiropoulos, D., Hatzis, T., \& Bousiou-Makridou, D. (2005). Guidelines for the design and implementation of e-learning Programmes, Proceedings of the IADIS International Conference IADIS E-Society 2005, 27 June- 30 June, Qawra, Malta.

Watson, M. D. (2005). Pedagogy before technology: Re-thinking the relationship between ICT and Teaching. Education and Information Technologies, 6(4), 252-266.

White, K. G. (2010). Beyond the horseless carriage: Harnessing the potential of ICT in education and training. Retrieved from: http://works.bepress.com/gerry_white/11/

Youssef, A. B., \& Dahmani, M. (2008). The impact of ICT on student performance in higher education: Direct effects, indirect effects and organizational change. RUSC: Universities and Knowledge Society Journal, 5(1), 45-56. 